\title{
Post-mortem Reproduction from a Vietnamese Perspective-an Analysis and Commentary
}

\section{Hai Thanh Doan ${ }^{1}$ (D) Diep Thi Phuong Doan ${ }^{1}$ (D) Nguyen Kim The Duong ${ }^{2}$}

Received: 7 March 2020 / Revised: 9 July 2020 / Accepted: 9 July 2020

Published online: 06 August 2020

(C) National University of Singapore and Springer Nature Singapore Pte Ltd. 2020

\begin{abstract}
Post-mortem reproduction is a complex and contested matter attracting attention from a diverse group of scholars and resulting in various responses from a range of countries. Vietnam has been reluctant to deal directly with this matter and has, accordingly, permitted post-mortem reproduction implicitly. First, by analysing Vietnam's postmortem reproduction cases, this paper reflects on the manner in which Vietnamese authorities have handled each case in the context of the contemporary legal framework, and it reveals the moral questions arising therefrom. The article then offers an account of Vietnamese social norms as an explanation for the tendency to conduct post-mortem reproduction. In arguing that a deeper and more thorough examination of the moral and ethical reasoning is required, the paper advocates in favour of supportive post-mortem reproduction regulation. In doing so, the paper seeks to reconcile the Vietnamese legal framework and post-mortem reproduction experiences of other countries. The article concludes that Vietnam and countries sharing the similar cultural traits should permit post-mortem reproduction explicitly. This would require full engagement with the ethical and legal issues arising, and careful promulgation of regulations and guidelines based on comparative experiences of a range of countries in handling this matter.
\end{abstract}

Keywords Post-mortem reproduction · Post-mortem sperm retrieval · Vietnamese legal system . Vietnamese indigenous belief . Confucianism

Hai Thanh Doan

Haidt16503@st.uel.edu.vn

1 University of Economics and Law, Vietnam National University Ho Chi Minh, Ho Chi Minh, Vietnam

2 University of Economics Ho Chi Minh, Ho Chi Minh, Vietnam 


\section{Introduction}

Due to breakthroughs in the field of biotechnology, treatments that were previously unrealistic and impossible are now at the disposal of humanity. Having a child with a deceased person or post-mortem reproduction $(P M R)$ is one of those treatments. PMR is a member of the family of assisted reproductive technologies (ARTs) and includes primarily in vitro fertilization (IVF) and cryopreservation (gametes or embryos), embryo transference or post-mortem gamete retrieval - this last case occurs when late people have failed to preserve gametes prior to death. There are several moral and legal dilemmas concerning this matter, typically the welfare of the future child, the autonomy of the deceased and the interest of the living.

PMR has been a controversial topic in Western countries since 1980 (Rothman 1980). In early cases, domestic courts and public authorities had to determine whether PMR was legitimate and allowable. To this day, no international consensus has been reached. Some scholars deem PMR, and in particular, post-mortem sperm retrieval (PMSR) - without explicit consent from the deceased-is immoral and unacceptable (Bahadur 2002). Conversely, some other writers advocate for 'presumed consent' in these cases (Young 2014; Tremellen and Savulescu 2015). Rosenblum (2013) developed the concept of the 'biological will' providing a rigorous foundation for the validity of the deceased's will concerning the fate of the gametes. Currently, while some states have passed laws and/or regulations to either legalize PMR and adopt operational mechanisms, e.g. the UK and Israel, or to outlaw PMR, e.g. France, others are still silent on this matter (Simana 2018).

In contrast to Western countries, in Sinic societies, i.e. the civilizations under the sphere of influence of Chinese cultural norms, PMR is a rather unexplored matter. Yet, there is strong evidence that this practice takes place. At least 4 children were posthumously reproduced in Japan from 2001 to 2004 (Ueda et al. 2008). In 3 out of the 5 cases, overburden and time-consuming legal actions were taken but failed (Ueda et al. 2008). Though China has already faced a PMR case, the related issues are still under-explored. In 2013, a young couple who had just had IVF treatment died in a car accident. To continue the bloodline of two families, the grandparents decided to impregnate a surrogate mother with the embryos. Nevertheless, their application to release the embryos was declined by the clinic because surrogacy is banned in China (Cook 2018). Instead of initiating a lawsuit with the hospital, the parents of the couple sued each other to attract the attention of the court to get permission to access the embryos (Cook 2018). The court opined in favour of their desire as follows: '...the only carrier of the two families' bloodlines carries the burden of their grieving memories and consolation' (Cook 2018).

As mentioned above, several ARTs are implicated in the practice of PMR. Some techniques, e.g. post-mortem ovum retrieval, may eventually be followed by surrogacy, furthering the quandaries and widen the scope of discussion by, either, incorporating dilemmas already regarding to surrogacy and/or by creating a novel set of issues. This paper does not attempt to address all of the issues but rather focuses on the fundamental issues at the core of PMR, particularly in the context of Vietnam. Part II of the paper gives an overview of PMR cases in Vietnam against the backdrop of the contemporary legal framework, also reflecting on the responses of Vietnamese authorities and scholars who have raised questions concerning the legitimacy and legality of PMR. 
Part III examines social norms orienting the Vietnamese approach and suggests an explanation of the motivations for conducting PMR. The paper then explores some objections against PMR and strives to make counter-arguments in Part IV. Part V proposes some tentative solutions for PMR based on lessons from Western countries. The conclusion is given in Part VI.

\section{How does Vietnam Handle PMR Cases?}

There had no documented case of PMR in Vietnam until 2013. On 9 December 2013, Hoang Thi Kim Dung gave birth to twin boys from the sperm retrieved from their father who had died more than 3 years previously (Tùng et al. 2013). At that time, there was only one relevant legal provision provided under the Decree 12/ 2003/NĐ-CP (Decree 12), which prescribed 'in cases where the sperm donor dies, the sperm storage facility must destroy that person's sperm count' (Article 8 of Decree 12), implying that PMR was illegal. Normally, after the donor's death, the practice had been that preserved gametes must be destroyed; hence, PMR had not been possible. However, there was no specific prohibition or sanction on PMR per se. It is not clear whether the Vietnamese authorities foresaw and wanted to outlaw PMR when passing the relevant Decree. In the instant case, to establish the fatherhood between the late husband and the twins, Dung brought the case to the commune Administrative Committee (Công lý 2014). Confused due to lack of explicit rules, the Administrative Committee asked for guidance from the Ministry of Justice and decided to record the father's name in the civil status certificate in line with Article 64 of the 2000 Marriage and Family Law (Công lý 2014). However, such a solution is open to question for a number of reasons: first, from a teleological perspective that would lead us to ask what is the primary purpose of the law, Article 64 is an out-of-wedlock child provision invented for cases where a husband has a child (children) with a woman who is not his wife when he was alive rather than as a means to regulate PMR cases which raise a plethora of novel issues; secondly, this reading is then at odds with the provision on 'identification of parents in case of giving birth with ARTs' of Decree 12. In the latter case, the woman's marital status is deemed to have ended from the point when her husband died; therefore, she would be appropriately defined as single and her late husband could not be recognized as the father of the new-born children.

Acknowledging filiation was the predominant issue in this case; nonetheless, several other issues were at stake but were under-explored.

First, as laws prescribed the destruction of preserved gametes once a donor died, I raise a very clear central question: 'Is PMSR lawful?' There could be two alternatives:

(i) If PMSR is unlawful, did the physician exert undue practice and hence, incur liabilities? If so, can he be charged for the crime 'intruding on human corpses' under the Penal Code (Article 319 of the 2015 PC)? If we are to suppose that PMSR is a crime, then this raises a further question: is the consent to retrieve sperm, if this existed, valid, and does it negate any crime?

(ii) If PMSR is lawful, what is the legal foundation for this practice? How can individuals carry out PMSR with authority and legitimacy (i.e. the requirements 
of valid consent and the required technical procedure)? Is there any restriction, particularly concerning the purpose and temporal scope, on this practice?

Second, regardless of the legality of the procedure, once the filiation is established between the deceased and the new-born child, can that child inherit from the deceased? If the child can inherit and is born after the bequeathment/partition, how can the interest of other beneficiaries be resolved?

Unfortunately, only a superficial response from the authority officials was given. Nguyen Huy Quang, Head of Department of Legal Affairs, Ministry of Health (MOH) articulated that: 'provided that the wife possesses the husband's sperm, regardless of the deceased's consent, 'it' is acceptable because 'it' is a personal right' (Tùng et al. 2013). The first-round debate may end as the widow has fulfilled her dream; nevertheless, Quang's response is ambiguous. What does 'it' refer to - the whole procedure or the use of sperm only? Whose personal right is it? What kind of personal right is it, and how far does it extend? The official response also prompts wider considerations: 'Are sperm (gametes) a personal right or a form of property?' If the former is the case, how can sperm be transferred and 'used'? If it is the latter case, can gametes and embryos be inherited, or even traded like other forms of property?

Despite these uncertainties and potential controversies, it is unfortunate that PMR was not covered in the new 2014 Marriage and Family Law (the 2014 Family Law). The Law was in its late drafting stages at the time when this case came to light. The 2014 Family Law illuminates and even highlights further the deficiency of the Vietnamese legal framework. Article 93 of the 2014 Family Law is premised on the presupposition that marital children or 'children in common' must be born within 300 days from the time of termination of marriage. A marriage is terminated by death or divorce. A single woman who gives birth to children with ARTs is the mother of the children. The new law incontestably shows that the application of out-of-wedlock child provision is inappropriate. A year after the 2014 Law was passed, Decree 10/2015/NĐCP (Decree 10), replacing Decree 12, was also passed. It was at this juncture that PMR was acknowledged in Vietnam, under Article 21 of the new Decree:

' 2 . In cases where the sperm, ovum [gametes] or the embryos donor is dead... the facility must destroy gametes, embryos of that person, except where a deceased person's spouse has a petition to keep and still maintains the storage fee

4. If the husband or the wife of a deceased using sperm as specified in Clause $2 \ldots$ of this Article and giving rise to relations other than the marital and familial relationship, provisions of marriage and family law and civil law is applicable regulate such relations'.

There is no official definition for 'relations other than marital and familial relationship' in legal documents and there is no consensus in Vietnamese scholarship. Due to the vagueness of the rule, difficulties in applying its provisions are sadly all too predictable.

In 2018, two PMR cases brought this matter back to public concern. The first case involved Pham Thi Hoa and Nguyen Thu Ha, respectively, the mother and the wife of the deceased (Duong Dang Khoa) - the only child in a veteran family (Hai 2018). After some years of living together, Khoa died of a stroke; before his last breath, he had stored his sperm at Hung Vuong hospital. After his demise, his mother and his wife 
then requested the return of his sperm samples but failed. In response to the request, the hospital required a notarial deed from the family (Hai 2018). The Notary Office, replying on the Law on Notarial Practice, declined to provide a notarial deed because sperm samples were not property (Hai 2018). The family reached out for help to the Ministry of Health (MOH) and to the public as well. In the correspondence 7531/BYTBM-TE, the Department of Health of Mothers and Children, acting in a representative capacity for the $\mathrm{MOH}$, stated that sperm samples were a common property of husband and wife and could, therefore, be inherited under a will or at law. Although the correspondence was good news for the family, it did not bring resolution of the raft of PMR issues. First, this governmental position triggers the same set of questions as were raised in the first case, namely, whether there is a requirement of consent and whether there is a time restriction of PMR, not to mention issues related to inheritance. None of these was satisfactorily answered because the correspondence simply briefly affirmed sperm is common property without elaborating on further legal implications. Secondly, the positions of representatives of the $\mathrm{MOH}$ in two different cases were inconsistent; in the first case, the representative of the $\mathrm{MOH}$ articulated that "'it' is a personal right", despite ambiguity, where 'it' might imply the characteristic of sperm (gametes), whereas, in a second case, the correspondence articulated that sperm is common property. Thirdly, the correspondence was not a normative legal document and not accessible by all of the population. Its legitimacy and accessibility therefore remain in doubt. Fourth, the correspondence failed to state the reasoning logically and clearly, and to provide a convincing solution to the scenario that the request for sperm represented. It affirmed that sperm was common property but it did not justify why sperm was property nor did it clarify how the beneficiaries could exercise their right to take the sperm back, i.e. What are the procedure and document that are required? The correspondence requested the hospital to let the widow undertake IVF in line with Decree 10. Nonetheless, there are good reasons to believe that due to differences between an 'ordinary IVF' and PMR, an application of provisions on IVF in ordinary cases would not be inappropriate, e.g. how can we sure that the decision to proceed with IVF has not been made due to grief? Fifth, it left many pertinent questions out of the discussions and opened further future dilemmas: 'How can the involved parties maintain the preservation of the sperm (by action or inaction)? Is this simply some kind of entitled to access to sperm for reproductive purposes (and so a clinic or hospital must act to preserve the gametes, potentially indefinitely)?, or must the beneficiaries act to take possession of the property, and if so how is this to be adequately preserved and used to reach the ultimate reproductive end? Thinking more broadly, if the deceased had not married before death in a legal sense, could sperm samples be inherited by his family? Could the deceased be permitted to leave sperm samples to his cohabitant or a third party apart from his wife?

A further case followed in the same year. Tuan, the only-son of Vong Thi Ngoc Huyen, had been seriously ill in 2014 (Yến 2018). Doctors advised him to preserve his sperm at $\mathrm{Tu} \mathrm{Du}$ hospital before commencing the treatment resulting in the preservation of Tuan's three sperm samples at Tu Du hospital (Yến 2018). Tuan then recovered and celebrated his wedding party in 2016. However, Tuan's health worsened thereafter and he died in June 2017 without registering his marriage at the People Committee (Yến 2018). His family requested the return of his sperm samples in order to undertake PMR. The 
case was covered by the media, and in the controversial context, for the $\mathrm{MOH}$, Quang reaffirmed that sperm samples were a kind of property but the widow could not take sperm samples back because of the non-existence of a formal marital relationship; accordingly, the sperm samples' ownership would have to be decided by a ruling from the court (Anh 2018). Quang's stance was challenged by several intellectuals including those revising the Civil Code (Luat 2018). Quang's statement is open to serious question for various reasons. One more time, the representative of the $\mathrm{MOH}$ seems to have omitted a vital step in reasoning, i.e. Quang did not explain why sperm is a kind of property; besides, despite affirmation that sperm is a kind of property, Quang outright stated that the sperm could only be inherited after a court's ruling without mentioning the possibility that-if this material genuinely is property in a traditional sense-then the sperm could/should be inherited at law without further formal process; there are no convincing arguments given for this stance. Indeed, Quang's statement might be contrary to provisions of the 2015 Civil Code because, if sperm is a kind of property, without further restrictions, it must follow that bereaved parents would inherit sperm in the instant case. A month later, in an interview about another PMSR case, Quang changed his mind and stated that 'once the prospective donor dies, his parents and wife are not entitled to receive the sperm samples [...] the samples should be considered as donated sperm' (Anh 2019). In light of all of this, more questions can be raised from Quang's statements:

(i) Can parties (the bereaved family, the cohabitant) access the court to claim the right to 'inherit' sperm and conduct PMR, and if so, how can they do so?

(ii) How can claims and disputes related to PMR be settled?

(iii) In the event that the existing inheritance regime is not applicable, is there any other way to determine the 'successor' of the preserved sperm, and should the successor be the bereaved parents or a cohabitant, if the deceased was not married?

(iv) Can the donor designate the successor of preserving sperm, potentially to include a party who is not his family and wife, when he provides the sperm to the hospital?

(v) Can, should, and how can the donor express his purpose for preserving sperm? For example, is the relevant deceased's interest only about reproduction or might this extends to donation for future research?

(vi) Supposing that the donor has expressed his intention when preserving sperm, are such statements equivalent to an explicit consent for PMR? If so, what does informed consent look like in such cases, and what is the formal procedure to obtain it?

Among opinions voiced, a strong position was put by Nguyen Phuong Lan, a law lecturer in Hanoi, who expressed the strong outright view that PMR is immoral and inhumane and consequence-unpredictable, albeit that this was done without any elaboration (Hoa 2018). Whether her statement is grounded and justifiable, it is undeniable that a discussion on the cultural and ethical aspects is required to evaluate the legitimacy and legality of PMR. 


\section{Vietnamese Social Norms—Its Implications for the Practice of PMR}

Despite an absence of sustained and rigorous examination as to its nature, the profound influence of cultural and social norms over the Vietnamese legal system should not be ignored nor underestimated (Nghĩa 2005). Vietnam is at the 'crossroad of civilization' (McLeod and Dieu 2001) and is, historically, an agricultural civilization that also has an inclination to integrate new cultural values into society as well (Nghĩa 2005; Thêm 2009). The Vietnamese tend to adopt different schools of thought without entire acceptance and adherence to any particular school. In ancient times, three leading schools of thought (Daoism, Buddhism and Confucianism) were transplanted into the Vietnamese social norms; over time, these interchanged with each other resulting in the so-called 'tam giáo đồng nguyên' (Nghĩa 2005; Lan 2016; Nguyễn 2013) orienting individuals' behaviour in society (Hiep et al. 1996). Confucianism is believed to have the most profound weight on ancient society (Nghĩa 2005; Vuong et al. 2018). Although some Vietnamese intellectuals have claimed that Confucianism was the wisdom of [Vietnamese] ancestors (Nghĩa 2005; Dinh 1970; Anh 2002), this stance has been challenged by some international scholars (Kelley 2020). Notwithstanding, reflecting the same content of the original Confucianism (Li 2018), the origins of Confucianism in Vietnam are less important than the influence that they have had on Vietnamese social norms. Due to the invasions from and occupations of Chinese dynasties - the latest from 1407 to 1427 - many Vietnamese cultural traits, including Vietnamese Confucianism, if this ever existed, as well as the influence of Buddhism in the Ly, Tran dynasty, were devastated by the oppression and assimilation of Chinese domination (see Whitmore 1984). Efforts of elites from the Later Le dynasty resulted in the significant influence of Neo-Confucianism over Vietnamese society (Whitmore 1984). Nevertheless, because the Vietnamese indigenous belief and other schools of thought did not entirely disappear, Vietnamese culture was still distinctive from the Chinese (Tran-Duc-Thao 1947; Whitmore 1984), albeit that due to abstract similarities, to a certain extent, there was a convergence between the indigenous belief and Confucianism. And, while the permeation into Vietnam of Western culture and philosophies, notably liberalism, may weaken the past values, particularly social norms of agricultural society and Confucianism, especially in the young generation (Mestechkina et al. 2014), these traits rooted for centuries have not abruptly vanished.

Traditionally, it can be seen that the Vietnamese ethos is shaped by three fundamental values: Hiếu [filial piety], Ân/n [moral debt] and Đức [virtue or humanity] (McLeod and Dieu 2001), and this shares an abstract similarity with Confucianism's ethos pattern. Both the Vietnamese ethos and Confucianism agree that filial piety is a fundamental ethical value that should be heavily stressed. Different to the Western belief that because a child does not give any consent for his birth, he or she owes no obligation to his/her parents, Vietnamese and Confucianism argue that the child would give consent, at least implicitly, proved by the maintenance of parental relationship dated from his birth (Wang 2001). Western and even Vietnamese intellectuals may explain that the pure reason underneath is 'the moral debt ... that he or she owed that would never be fully repaid' (McLeod and Dieu 2001; Wang 2001); this is demonstrated by proverbs about 'công cha, nghĩa mẹ' [parents engagements and deeds] but it is not comprehensive. Fan's (2007) stance may accurately reflect a common belief that filial piety derives from 'the reciprocal relationship between family members'. This 
position is reflected in several instances, e.g. there is a proverb that reads 'máu chảy ruột mềm' [Blood shedding, the intestine softening].

Contrary to Whitmore's belief that a typical Vietnamese family is 'a nuclear family' together with "'village' forming major element of social organization' and 'unlike in China, the elements of the family were not tied eternally to each other' (Whitmore 1984; Yu 1978), the Vietnamese people do value clan and extended family (McLeod and Dieu 2001). A couple used to have multiple children and the eldest son (in the North) or the youngest son (in the South) was obligated to take care of his parents. The other children were independence and their family was per se nuclear; nonetheless, sons seldom moved distant from their homeland (McLeod and Dieu 2001). Confucianism teaching was that of 'tam tòng' [three-subservience], i.e. that after marriage, a woman must follow her husband wherever he goes, and Vietnamese proverbs and folk poems warn [girls] against marrying someone who does not live nearby ('Chồng xa'); hence, there was an inclination that marriage occurred almost exclusively within a village. However, villages should not be perceived as a distinct institution from family but rather a kind of extended family. This, together with needs to cooperate in agricultural life, explains the close tie with the village (Thêm 2009). It also sheds light on a preference for harmony, collectivism and respect for the elders, predecessors of the Vietnamese people (Nghĩa 2005; Thêm 2009).

Filial duty is not limited to the moral obligation towards parents; it extends to all familial predecessors. Traditionally, 'tết' is the event when descendants reunite and wish the longevity and health for the elders. Besides, according to the Vietnamese indigenous belief, being' is constituted by soul and body. The Vietnamese believe in the separation of souls from bodies, so that after leaving a body the soul of a deceased person will continue to look after and protect their beloved and progeny. Hence, almost all Vietnamese practice ancestor worship ('thờ cúng ông bà') in ways that aligned with their religious beliefs (McLeod and Dieu 2001; Anh 2001). Ancestor worship is practiced daily in each house. There is an anniversary ('ngày giỗ') every year when family members, relatives, etc. gather together to light incense burner to remember the deceased and a day called 'thanh minh' when descendants visit and clean ancestral tombs. Further, ancient and contemporary Vietnamese laws allow a unique kind of unsellable parcel of land called 'hương hỏ' [incense and fire] that is distributed exclusively to maintain ancestral bond. Hence, the Vietnamese people favour the abundance of descendants, expressed by proverbs such as 'con đàn cháu đống' [herds of children, piles of descendants] and worry about ending the bloodline. This is reflected in the famous quote of Meng-Tzu ‘不孝有三, 無後為大' [There are three unfilial acts, to die without an offspring is the gravest one] (Quinn 1973; McLeod and Dieu 2001). It follows that marriage, the sacred mechanism to maintain the lineage, is believed to be 'a matter of two people but establishing the relationship between two families' (Thêm 2009; McLeod and Dieu 2001). Marriage, therefore, must go through several stages, accepted by both couples and their families (parents or even grandparents), and be formally celebrated with the participation of clans. It used to take several years from the first discussion of families to betrothal ('lễ hỏi') and wedding ('lê̂ cưới') (McLeod and Dieu 2001).

Besides affection, marital relationship is typified by spousal debt ('ơn/tình nghĩa vợ chồng') indicating that husband and wife have a moral obligation to support each other, particularly in hardship. Voluntary sacrifice of self-interest for the interest of the spouse 
is highly valued. Nonetheless, Vietnamese women are relatively equal to their husbands and have a voice on familial matters (Yu 1978; Thêm 2009; McLeod and Dieu 2001).

Therefore, from the Vietnamese social norms perspective, all of this suggests that there can be forces behind motivations to seek PMR. To summarize, Vietnamese cultural reasons to support PMR may include

(i) the acceptance of 'family' and kin being a much wider circle of persons than in other cultures, especially the West;

(ii) the significant importance of a family line not dying out, and the overriding moral obligation not to die without offspring which may explain why a deceased person and bereaved parents may accept and be inclined to conduct PMR; and

(iii) the powerful duties owed between spouses, and between family members which may indicate, in particular, a woman's tendency to fulfil her husband's will, including the bloodline continuity, and to take care of family members, particularly her husband's parents. This might explain the 'moral force' behind a woman's decision to conduct PMR.

Nonetheless, social norms can be a double-edged sword, and further reflection and reasoning is required on the social and ethical issues in play. In the next section, some reasons that have been advocated against PMR are subjected to analysis and critique, relative to the cultural context that has been outlined here.

\section{Some Objections Against PMR and Responses}

\section{First Objection}

This objection challenges the belief that death pays all debts: is it moral to 'impose responsibility' on the deceased (Landau 2004) or 'exploit' the deceased's body to pursue one's own dream (Landau 2004; Orr and Siegler 2002)? This argument consists of two counts: (i) respect for the autonomy of the deceased and (ii) the integrity of the deceased's body. Central to these claims is the notion that deceased persons can have interests that deserve respect. The arguments are well-rehearsed and do not required repetition here. Suffice to say that deceased person's interests are already recognized: a deceased person can leave a will to transfer his estates or to donate his organ, and the law in many countries recognizes malicious acts against the deceased, e.g. defamation is punishable (Côté et al. 2014; Kramer 2001; Smolensky 2008). Based on the interest theory, Kramer and Smolensky even go as far as to assert that deceased people may well have rights (Kramer 2001; Smolensky 2008). Taking the interest-based perspective as a starting point, we can consider the two points of the argument laid out above.

\section{Autonomy}

This issue is most easily resolved if explicit consent is given prior to death. Otherwise, some 'pro-restrictive' intellectuals have argued against implicit consent for PMR because, it is claimed, it is alien to society (Lin 2013; Schiff 1999). Furthermore, the objection is made that the deceased may have an interest in control over posthumous reproduction, and that 
such an interest may go as far as an interest not to reproduce posthumously (Ethics Committee of the American Society for Reproductive Medicine 2018). Specifically, the interest in not having children after one's death is more than an interest in avoiding certain experiences, e.g. there is an interest in avoiding having children that one will not be able to raise and nurture (Ethics Committee of the American Society for Reproductive Medicine 2018). Barton tried to distinguish between acceptance of PMR and the requirement of prior consent and showed that only a minority of persons who were asked favoured implicit consent (Barton et al. 2012). Nonetheless, Barton's findings may be confusing and inconclusive. For example, questions 4 and 5 of Barton's survey ask that 'in the event of death of a man/woman, do you believe his partner should have access to his sperm/eggs in order to have a child after his death?' There are three alternatives, 'yes', 'no' and 'do not know'. Regardless of the answer in questions 4 or 5, all respondents can answer question 6 that 'Do you believe prior consent ... should be required...? (If No, skip to question 8.)'. This means that opponents to PMR and undecided respondents can still reply to the requirement of prior consent. Moreover, there are three alternatives to answer question 6: 'yes', 'no' and 'sperm or eggs from the deceased should never be used to make a baby, regardless of consent'. If the answer is 'yes', respondents turn to question 7 that asks: 'If death was sudden ... are there circumstances when a partner should be allowed to decide to retrieve sperm or eggs without prior consent from the person who died'. The figure of respondents who did not require prior consent was not shown, while $33.9 \%$ of $72.8 \%$ of those requiring prior consent agree with waiving of consent in some circumstances (and 24.9\% were undecided) (Barton et al. 2012). The research does not, therefore, show the full number of proponents in favour implicit consent, whether in all cases or particular cases, and this might not be as small as suggested by Barton. This said, Collins and Simana point to very real practical problems with a prior consent approach, notably that death can be suddenly and unanticipated (Collins 2005) and discussion on PMR with the family or wife is quite a specific topic and might be seen by many as depressing (Simana 2018).

Turning to the question of acceptance of PMR, regardless of notable errors such as the bias of respondents and emotional indifference, empirical research has shown a high level of acceptance (Hans 2014; Barton et al. 2012; Nakhuda et al. 2011; Pastuszak et al. 2013). As stated above, deceased persons may have various interests, e.g. reputation and the welfare of his/her beloved, and the interests of each deceased person, as well as the gravity of each interest for him/her, are not necessarily the same. Still, as posited by Smolensky, the interests of deceased persons are all driven by the dignity of the deceased and the innate desire among the living to honour the wishes of the deceased (Smolensky 2008). Although Smolensky leaves a possibility that decedents' wishes can negatively impact interests of the living (Smolensky 2008), against the background of the Vietnamese cultural values (derived from harmony, filial piety, spousal debt) as outlined above, it is possible to argue that a presumptive ethical position with respect to a deceased person's interests in Vietnam is either to align this with his living beloved's interests or to assume a degree of altruism with respect to wider family interests. For example, Vietnamese culture has the proverb 'Cọp chết để da người ta chết để tiếng' [When a tiger dies, it leaves the skin, when a person dies, what survives is his name] to emphasize the long lasting of the dignity and reputation of deceased people. Vietnamese cultural values recognize the dignity of the deceased people, and it is reasonable to assume that the deceased's interests are not contradictory to the interests of his beloved persons, particularly, his/her family. Indeed, building on Smolensky's stance that the 
living may well recognize the dignity of the deceased (Smolensky 2008) and ought to safeguard the interests of the deceased's, e.g. his/her dignity, it is arguable in the Vietnamese context that there can even be a moral responsibility of a family to do so. The position of Vietnamese cultural values may reflect and consolidate the argument of authors such as Collins and Simana that genetic continuity is 'desired' by the deceased (Collins 2005; Simana 2018; Ossorio 2016; Callaway 2015) and the family is best to interpret the deceased's wishes (Simana 2018). This position promotes the view that the presumptive autonomy of the deceased ought to be respected, except when to do so otherwise violates the interests of others.

In contrast, this view must accept that the deceased's interest should not overwhelm the interests of the living, primarily the wife. So, for example, a presumed dissent cannot overrule the explicit consent of the living. This has even been recognized in law. In Nahmani v. Nahmani, the Israeli Supreme Court even went further to hold that '...a woman's rights to procreate [...] take precedence over her husband's right not to be a parent'. Conversely, and reflecting a communitarianism context, it can be argued that the implicit consent is particularly appropriate for Vietnam and other Sinic civilizations.

\section{On the issue of integrity and 'use' of a corpse}

This issue involves both legal and moral aspects and the discussion here is offered a separate issue from 'consent', presumed or otherwise. There are two sub-issues in this regard, first, whether PMSR violates bodily integrity [of the corpse], and second, whether PMSR uses bodies in an unethical/illegal manner.

The first sub-issue may be quite contentious as moral pluralism may lead to various views of the threshold of violation of bodily integrity. Although contemporary Vietnamese laws do not address this issue specifically, by referring to a cultural traditional perspective, it can be argued that PMSR is a medical procedure that does very little to invade the body since gametes are not organs in the eyes of Vietnamese law: see Article 3(1) and 3(2) of the 2006 Law on donation of corpses. In fact, gametes are cells that can be separated from the body without jeopardizing it, i.e. physical integrity is maintained. Moreover, the respect of the Vietnamese to deceased persons is also demonstrated by the Le Penal Code that condemns and criminalizes acts against the integrity of the corpse. This having been said, according to the Le Penal Code, only physical damage to the corpse is counted as the violation of the integrity of corpses (Article 442, 443). There is, therefore, a convergence between Vietnamese belief and Confucianism in this matter as contemporarily, disfigurement or other forms of bodily mutilation are not favoured in medical practices (Hui 2001). It can be deduced that the removal and storage of sperm do not cross a threshold of invasiveness or violation akin to these kinds of concerns or crimes.

Concerning the second sub-issue, the position advocated in this paper agrees with Strong and Kishore that if it is accepted in society that the bereaved family can donate tissues and organs for non-commercial use/benefit of a third party, then why cannot the family use/benefit from a deceased relative's tissue/organs for themselves (Kishore 2017; Strong 1999)? Is there an implication that donating gametes, tissues or organs to satisfy the needs of someone else is humane, while fulfilling the emotional needs of the bereaved family is egocentric and inhumane? This is illogical. If this analogy is accepted, it would follow that it is inappropriate to deem PMR (PMSR) as necessarily 
unethical if the concern is only in the use of bodily material from a deceased person. Diana Lin (2013) may be more accurate in asserting that the quandary is about the significance of bringing a new life to the world. Further consideration to such counterarguments is given in the paragraphs below.

\section{Second Objection}

As to a second core objection, some scholars argue that PMR 'creates for women a moral and psychological obligation that infringes on the woman's liberty and autonomy' and the surviving partner 'may well be subject to intense pressure from her husband's parents...' (Landau 2004; Aziza-Shuster 1994). Although the comments were made against an Israeli Posthumous Sperm Retrieval and Use Guidelines (the 2003 Guidelines), they are very applicable to the context of Vietnamese and Sinic civilizations.

Foremost, we must ask the most appropriate question about what is at stake. In particular: 'have any of us ever lived free from moral and social constraints?' Even assuming that liberalism is the universal principle of morality, viz., humanity lives relatively free from moral and social constraints, once the husband dies and a marriage is terminated, a woman owes no obligation to her husband's family; she can live the life she wants. She is free to re-marry and no defensible argument could be offered to the contrary. Landau's concerns, therefore, may be too far-reaching in this context. Nonetheless, it must be recognized that as human beings we are a kind of social animal; we cannot separate ourselves from the norms of the community in which we live. Landau's concerns about social pressure, vulnerability, and the risk of exploitation are therefore entirely understandable. However, while some general sense of moral obligation is common, a specific moral obligation to conduct PMR is not that common, viz., while some people may feel the obligation to conduct PMR, others may do not. The question is whether the threat of coercion is so great as to overwhelm any argument in favour of autonomy-based PMR. A well-designed regulatory system can promote respectful PMR while sanctioning instances of coercion, as would be appropriate if undue influence was put on women to follow a dead husband's parents' wishes.

It is important to recognize that in a community-based society like Vietnam, the relationship between the husband's parents and his wife may not be terminated after his death; the widow may, not in an obligatory sense but rather as an emotional bond between family members, continue to take care of and fulfil the filial duty to the deceased parents. 'Emotional stress' is relevant and might be significant but this risk should not be read in isolation, nor should it ignore all legitimate wishes of women themselves. Landau cites Aziza to argue that presumed consent is the problem in familial pressure cases (Landau 2004; Zini and Mak 2001). However, I would argue that 'moral coercion' exists in both presumed and explicit consent contexts. In the latter case, it is very unclear that the will of a dead person diminishes moral coercion, or otherwise, puts more weight on it. Rather, the key question in this issue is whether the woman herself makes a free, valid decision. Although the risk of moral coercion can be exacerbated by social norms and expectations, to acknowledge this does not necessarily mean that we must outlaw PMR, but equally, it might suggest that important checks and balances are put in place to ensure the legitimate wishes of a woman are established and that there is not undue coercion. 


\section{Third Objection}

Some scholars argued that PMR 'is a bid for immortality...' (Carbonnier 2000) and '... exploits the dead not to prolong an existing life but to create a new one' (Landau 2004). Nevertheless, the extension of parenthood, despite being condemned as unethical by some scholars, is praised by others as a means to maintain social values (Simana 2018; Kishore 2017). The divergence of views on whether the extension of parenthood is moral may lie with the plurality of morals, viz., different people, and different cultures may have and may use different systems of ethics (interpersonal pluralism). Kantian philosophy may shed light on this issue since, as Thomas E. Hill may rightly pointed out, contrary to some beliefs, 'Kant's ethics, suitably reconstructed, can be regarded as pluralistic' as 'the right and duty is determined by rational reflection from the point of view that counts each agent as equally authoritative regarding moral principles and equally free to set and pursue individual ends within the limits set by these principles' (Hill 1992). Kantian philosophy provides a coherent system to tell whether an act is moral or not (Schaber 2005). For Kant, individuals are free provided that they act following 'the Categorical Imperative', viz., the moral principle which they establish, and individuals should not be treated as merely a means to an end (Kant 1785). Both points above, in no way, mean avoidance of happiness. Inheriting the deceased's name and family's tradition is inherently part of one's self-cultivation process (Hui 2001). In particular, PMR or whatever kinds of reproduction should not be assumed as treating a child merely as a means. Manifestly, 'using' a child only to harbour someone's figure or to achieve someone's wishes is morally wrong; however, this is not an inevitable or exclusive outcome with PMR and indeed is a concern in all instance of reproduction. A prohibition or restriction on PMR is justifiable if only similar instances are restricted or banned with artificial reproduction in other circumstances, which is not the case.

There can be concerns about whether the deceased is treated as merely a means to an end, but there are good reasons to challenge this. First, the deceased's autonomy is the foremost concern for the inclination to conduct PMR; acknowledging the deceased's autonomy and honouring the deceased's wish should not be construed as treating the deceased as merely a means. Second, it is hard to believe that the living (e.g. the spouse, the parents of a deceased person) may treat the deceased, their beloved, the one with whom they have certain reciprocal moral obligations (e.g. spousal debt), as merely a means to an end due to a mere desire to have a baby born. Currently, only the spouse of a deceased person has a say in conducting PMR (this point is elaborated later). If a decision to conduct PMR is driven exclusively by a desire to have a child rather than a combination of a desire to have a child and sincere emotions for the deceased, the spouse can have a child by employing other means, e.g. becoming pregnant with an anonymous gamete donor.

\section{Fourth Objection}

One of the biggest challenges against PMR is the concern for the welfare of a child. Some scholars have invoked the UN Convention on the Rights of the Child to remark 'in all issues involving children, the rights of the child have priority over other interests' (Landau 2004) and go further to argue that in PMR cases the child's interest is ignored because the child would be growing up 'fatherless', in an 'incomplete family structure' 
(Lee and Morgan 2001; Wardle 2006; Parizer-Krief 2016). Though well-meaning, the argument here is based on a dubious presumption. Foremost, I would like to address this challenge on par with the right to reproduce as both are fundamental human rights (UNFPA, OHCHR, and the Danish Institute for Human Rights 2014). The premise of the reproduction right, from ethical and philosophical perspective, is the right to freedom and self-determination (Kishore 2017). Thus, the Israeli Supreme Court opined in Nahmani v. Nahmani that 'if you take parenthood away from someone, it is as if you have taken away his life'. The right to reproduce was also coined from right to a family and to be respect for private and family life, such as found in the International Covenant on Civil and Political Rights (Article 23(2)) and the European Convention on Human Rights (Article 8(2)). The notion of right to procreate has progressed and embraced, inter alia, the right (i) to decide freely and responsibly whether or not to have children, (ii) to have information and means to reproduce and (iii) to attain the highest standard of reproductive health. Husband and wife are in the driving seat to decide responsibly reproductive matters with which outsiders should not interfere. On this basis, it is arguable that widows should not be forced to 'wait and find another man' or 'adopt a child' (Simana 2018). Moreover, there is no immediate or automatic conflict between parenthood and a future child's interest. 'Fatherless' is invoked as a misfortune, but it is possible to pose a different question: 'what distinguishes PMR from IVF cases involving a single woman?' Bearing in mind that the latter case does not always afford the children's right to know their origin (Ravitsky 2017; Amorós 2015) and a joyful 'home' with generations, both are precious values in Eastern Culture. The fact that billions of children are in poverty does not mean it would better to ban their birth. Besides, although being fatherless might be seen by many as a misfortune, it does not indicate that a child therein will certainly be disadvantaged. It is reported that in the solo-mother family the children continue to function well (European Society of Human Reproduction and Embryology 2016). Some countries, e.g. UK and Vietnam, now no longer require the 'need for a father' as a prerequisite to access to ART; the requirement of 'a father', indeed, can be a potentially discriminatory for some groups seeking access to ART, e.g. single women and lesbian couples. The parallel is strong for PMR.

\section{Fifth Objection}

There may be a concern that allowing PMR encourages this practice; additionally, PMR 'could be a source of complications in [...] especially inheritance rights, where abuses might follow' (Parizer-Krief 2016). But avoiding these challenges by inaction or indiscriminate prohibition can also have paradoxical results. Individuals seeking PMR may somehow find ways to undergo so-called procreative tourism and even engage in illegal medical practices. A ban on PMR by criminalizing the conduct is overly intrusive in ways that might violate the right to decide freely family matters while not necessarily stopping the practice or promoting the status and rights of the child. Both prohibition and inaction inflict undue burdens on citizens, particularly marginalized people (the poor, the disabled) and women more generally. By depriving people of the right to information and means to reproduce can lead to deterioration of reproductive health and access to PMR via illegal/under-qualified medical facilities/practitioners. 
In brief, oppositions to PMR, from liberalism, communitarianism to feminism, are incoherent and unsubstantiated.

\section{An Approach for Vietnam and Sinic Civilization Nations?}

Vietnam has shown an acquiescent attitude towards PMR. From the analysis, legalizing PMR by detailed, accessible regulations is justifiable. Since Western nations are experienced in this matter, a contextualization-based approach is appropriate for Vietnam (and other Sinic civilization nations); however, such an approach should take into account the legal framework and special traits of each country, I shall address some notable issues of PMR hereunder.

\section{Property Issue}

Whether or not gametes/embryo is property is a relevant but not decisive point for PMR-related issues since states can vindicate their stance and relieve this issue by deploying different accounts, typically, the account on 'intent'. For instance, in the French case Parpalaix v. CECOS, the court allowed the return of preserved sperm of Alain Parpalaix to Corrine Parpalaix for the reason of 'intent' (this issue will be discussed in below paragraphs), and the court refused to grant property status to sperm samples because:

First, sperm cannot be considered divisible from the body of the donor in order to protect the integrity of the human body; hence, it is not movable, inheritable property (See more (Katz 1998)). It had long been established that 'no one is to be regarded as the owner of his own limbs' [Dominus membrorum suorum nemo videtur] (Ulpian, D.9.2.13 pr), and 'if there could be no ownership of a human body when alive, how can death trigger ownership of it'. In England, in Reg. v. Sharpe (1857), Rose LJ articulated that '...neither a corpse nor parts of a corpse are in themselves and without more capable of being property protected by rights...' The Vietnamese Law recognizes body, limbs and organs as belongs to personal rights in Article 35 of the 2015 Civil Code.

Nevertheless, the presupposition of the French court can be challenged because gametes, specifically, sperm, are distinct from parts of a human body and a human corpse. Concerning Vietnam, despite being regulated by the 2006 Law on donation of corpses, there is an indication that gametes and corpses, tissues and organs are distinct as (i) gametes do not fall under the definition of tissues and body parts as provided under Article 3.(1) and 3.(2) of the 2006 Law on donation of corpses; Article 3.(1) provides 'tissue is a combination of cells of the same type or different types to perform certain functions of human body'. Article 3.(2) provides 'human organ is a part of human body formed from tissues of different types to perform certain physiological functions' and (ii) they are regulated in separate provisions, respectively, Article 5 and Article 6 of the 2006 Law on donation of corpses. From an ethical perspective, as stated above, the extraction of gamete does not necessarily violate the integrity of the body, and, presumably, gametes are not body parts, as such. An assessment of the property status of gametes should be taken from analysing its merit rather than from making an analogy with parts of a human body and a human corpse. 
Second, as stated in Parpalaix v. CECOS, gametes are " "the seed of life ... tied to fundamental liberty of a human being to conceive or not to conceive... This fundamental right ... is not to be subjected to the rules of contracts" The person from whom it is drawn must decide the fate of the sperm; therefore, the sole issue becomes that of intent (Shapiro and Sonnenblick 1987). This issue will be unpacked below.

Currently, some jurisdictions have asserted the property status of gametes; for example, US jurisdictions recognized gametes as a distinct category of property in Davis v. Davis and Hecht; in 'Re the estate of the late Mark Edwards', the Supreme Court of New South Wales affirmed that sperm is a property; in K.L.W., the British Columbia Supreme Court held that sperm are property in certain contexts. In the UK case of Yearworth indicated the same. Several accounts have been offered in favour of the property status of gametes.

First, some cases may indicate that donors may have a legal interest in gametes which is akin but not identical to ownership. In the case of Davis v. Davis, the Court held that ' ... [The biological parents] do have an interest in the nature of ownership, to the extent that they have decision-making authority concerning disposition of the preembryos, within the scope of policy set by law'. In Hecht, the Court held that '.. at the time of his death, decedent had an interest, in the nature of ownership, to the extent that he had decision-making authority as to the sperm within the scope of policy set by law. Thus, decedent had an interest in his sperm which falls within the broad definition of property in Probate Code section 62, as 'anything that may be the subject of ownership and includes both real and personal property and any interest therein.' In Yearworth, it was held that 'the sole object of plaintiffs' ejaculation of the sperm was that, in certain events, it might later be used for their benefit' and '...no person, whether human or corporate, other than each man [the plaintiffs] has any rights in relation to the sperm which he has produced'. In 'Re the estate of the late Mark Edwards', the Supreme Court of New South Wales stated '...Ms. Edwards is the only person in whom an entitlement to property in the deceased's sperm would lie. The deceased was her husband. The sperm was removed on her behalf and for her purposes. No one else in the world has any interest in them [...] it would be open to the Court to conclude that Ms Edwards is entitled to possession of the sperm' The position of the latter two judgements can also be read as in favour of the status of gametes as 'res patrimonio' rather than 'res extra patrimonium'.

Second, if gametes can be owned, property law is applicable, even if this is in a limited sense with regard to the appropriate disposal or reproductive use of the gametes; this can benefit the owner to exercise his/her right to use and transfer the gametes and defend against any violation on the gametes. Besides, according to Reid 'a property model, moreover, corresponds with prosaic reality. In practice, body parts are often treated as if they are owned. They are donated, preserved, worked on, and abandoned. The very language used to describe these activities is the language of property law. The law should be in alignment with the practice' (Reid 2015). As stated above, gametes are distinct from body parts; nevertheless, Reid's argument, referring to body parts, applies to gametes as gametes can similarly be treated as if they are owned.

Third, there may be an objection that an "acknowledgement of the property status of gametes is tantamount to a 'commodification' of gametes by reducing them to a cash equivalent ... the very label "property' diminishes the respect due to human parts" (Bennett Moses 2014). But, as pointed out by Reid, 'applying property law for gametes 
does not necessarily means gametes can be sold' (Reid 2015). Restrictions on certain rights in the 'bundle of rights' does not go against property law. Cases concerning gametes have recognized that gametes are not an ordinary property. In Davis v. Davis, it was held that '...embryos should not be treated as standard property given their special nature as potential life ...' the same was held in case Hecht. In Yearworth, the Court acknowledged the limitations on gametes ownership and gave justifications for such limitations by exemplifying circumstances where certain rights of ownership would be restricted: 'their rights to its use have been eroded to a limited extent by the Act but, even in the absence of the Act, the men would be likely to have needed medical assistance in using the sperm ... For two reasons, however, the absence of their ability to 'direct' its use does not in our view derogate from their ownership. First, there are numerous statutes which limit a person's ability to use his property - for example a land-owner's ability to build on his land... - without eliminating his ownership of it. Second, by its provisions for consent, the Act assiduously preserves the ability of the men to direct that the sperm be not used in a certain way: their negative control over its use remains absolute'. Concerning the argument on the erosion of the ability to arrange for gametes to be stored, the Court held that '...the significance of these inroads into the normal consequences of ownership [...] is, again, much diminished by the negative control of the men, reflected in the provisions that the sperm cannot be stored or continue to be stored without their subsisting consent. Thus the Act recognises in the men a fundamental feature of ownership, namely that at any time they can require the destruction of the sperm'.

Concerning Vietnam, currently, from the legal perspective, gametes can be acknowledged as property because (i) gametes are not body/corpse parts as such and (ii) gametes can fall under the broad classification of property 'objects, money, valuable papers and property rights' as provided under Article 105 of the 2015 Civil Code. The 2015 Civil Code neither defines 'property', nor determines essential characteristics of 'property', nor clarifies each item thereof. It can be argued that gametes can be recognized as 'objects' which, according to Nguyen Ngoc Dien, an expert in Vietnamese property law, [objects] refer to tangible things (Điện 2018). Nevertheless, taken together both legal and ethical perspectives, the property status of gametes in the Vietnamese context can be contentious. According to Nguyen Ngoc Dien, the vital essence of property is [economic] value; he inclines to the view that the value of property is determined by transaction/market, though an actual transaction/transfer of title is not required and even cannot be carried out in reality (Điện 2018). Bearing in mind that the Vietnamese give enormous respect to the elder, deceased people, corpses, while neither extracting gametes nor using them for PMR is disputable, a viewpoint that gametes have value, viz., gametes are a kind of commodity, can be made. However, an emphasis on the economic value of property may not be convincing or ethically acceptable, particularly concerning gametes. If the value of an object is decided by the market (demand and supply) rather than the mere fact that property law is applicable to protect the interest of the holder/'owner' on that object, then much can be missed about the ethical and social reasons why we seek to apply property and control to certain objects; moreover, there are instances, which are also recognized by Nguyen Ngoc Dien, where an object has value but is not a property, e.g. [in some countries] guns, narcotics (Điện 2018). The core 
questions that require answering to affirm that an object can be a property should be (i) if someone may have particular interests in that object or someone can make use of that object and (ii) if that object is subject to possession and disposition of someone, viz., if there are sufficient sticks [of the bundle of rights] to be counted (Article 158 of the 2015 Civil Code).

This paper favours the view that gametes should be recognized as property with some restrictions: (i) gametes are not sellable and (ii) only the spouse of a deceased person (or the deceased's parents in some instances, i.e. in the case where a wedding has taken place but the marriage registration has not been completed) can receive/have rights over the gametes because (i) the 2015 Civil Code has sufficient grounds for such a recognition (as mentioned earlier) and (ii) recognizing the property status of gametes can better safeguard the interests of the donor (the deceased) and bereaved family, e.g. the donor may defend gametes against violations of others, the bereaved family (particularly the deceased's spouse) can inherit gametes and 'use' it for PMR. Issues concerning subjects having rights to inherit and use gametes [to conduct PMR] will be examined below.

\section{Permission, Consent/Intent and Consent Formality}

Consent (or intent) of a deceased person can be relevant, pivotal and even obligatory, both in a legal and ethical sense, with respect to several aspects of PMR, including PMSR, and also regarding return of gametes from medical institutions. First, as mentioned above, consent is the key to address concerns about the autonomy of deceased persons and can resolve one of the objections about the legitimacy and validity of PMR. Unjustifiable disregarding of the requirement of consent (intent) of deceased persons is morally wrong since it is equivalent to violation of autonomy (Orr and Siegler 2002; Batzer et al. 2003). As a result, consent sought be sought were possible. Second, supposing that gametes are considered as a form of property, then the consent/intent of deceased persons is relevant to determine the successor(s) of the estate. Bearing in mind that, as mentioned in the preceding section, an acknowledgement of the property status of gametes can be 'sensitive' and 'contentious', gametes may have an intermediate status - somewhere between a piece of inheritable property and an actual life (Katz 1998), the will of the deceased becomes the primary account for the 'inheritance'/'returning' of gametes. For instance, in case Parpalaix v. CECOS, the court decided the issue on returning of sperm based on the account on the 'intent' (or consent) of the deceased to conduct PMR by holding that 'a person's intent to bear children must dictate the use of the sperm...', viz., whether or not the deceased consent to conduct PMR.

Nonetheless, consent is insufficient in some instances, e.g. Portugal bans PMR except for embryo transference. According to Raposo (2012), there are two reasons for this exception, first is the 'presumed consent' does not apply to PMR, second is the analogy between 'in vitro embryo' with 'in uterine embryo', viz., a beginning of life has existed.

Often, different PMR-related techniques can be carried out under the same consent formality but with specific procedural steps. Consent formality varies among states, Israel takes a 'presumed consent' approach, while the UK, Belgium, Canada and Australia primarily prefer a signed written consent; however, there are some 
exceptions, in England in the case of Blood, sperm was collected without written consent and was lawful to allow the wife to seek PMR abroad under European law, and in K.L.W., the widow was allowed to use her spouse's preserved sperm even though there was no written consent (Shebbeare 2016). The Supreme Court of New South Wales in 'Re the estate of the late Mark Edwards' permitted Jocelyn Edwards to use extracted sperm without written consent from the deceased. Both Greece and Spain require a notarized written signed consent; nonetheless, while Spain leans towards presumed consent regarding embryo transference, Greece leans towards the restrictive approach.

As stated above, PMR should be accepted in Vietnam. A distinction between gametes and the embryo similar to that in Portugal may not necessary for Vietnam because (i) Vietnam does not condemn PMSR as unethical and (ii) it is doubtful that gametes or in vitro embryo achieve the personhood in the context of Vietnam.

Compared to presumed consent, more countries prefer explicit consent. The reason for the inclination to explicit consent is that it can express clearly the intent to become a parent posthumously of a deceased person. Concerning explicit consent, there are three alternatives, verbal, signed written and notarized signed written consent. Since death is unpredictable and sudden, notarized written signed consent has little practical meaning in PMR cases. Moreover, a notarial deed is a formal requirement which is necessary for two purposes: (i) to ensure the legality and authenticity of a transaction and (ii) to ensure the accuracy of documents whereas in PMR cases, the deceased's spouse is the only person entitled to conduct PMR in the argument of this paper; the de jure (or de facto) marital relationship can be verified by various means, e.g. marriage certificate, verification of the deceased's parents, verification of local authorities; the need of a notarial deed is not as high as in wills to distribute the estate ('ordinary' wills). Notwithstanding, in 'ordinary' written wills, the notarization is not mandatory (Article 630.(1) of the 2015 Civil Code). Verbal consent can be acceptable because, as stated, the death is unpredictable and if at the last breath, a deceased person expresses his consent for PMR, his wish should be honoured. In 'ordinary' wills, according to Article 629 of the 2015 Civil Code, 'where a person is likely to die due to illness or any other reason and it is not possible for him/her to make a written will, such person may make an oral will...' Hence, both verbal and written consent should be accepted.

Presumed consent should also be acceptable. Presumed consent has been endorsed both by countries favouring liberalism and those inclining more to communitarianism. Even in France, the country has a long history of banning many ARTs (contemporarily including PMR), but the court in Parpalaix $v$. CECOS held that 'the fact that there was no prior written contract outlining the posthumous use of the sperm did not necessarily indicate that Alain never intended for Corinne to use the sperm' (Katz 1998). Israel, the country which has a preference for family akin to Vietnam, states in its 2003 Guidelines that the deceased's spouse commonly and naturally shares this desire for continuation (Westreich 2018). According to the Guidelines, 'the desire for continuation is a fundamental desire of most parts of the Israeli society ... even if this was not explicitly expressed, the agreement of the spouse to the process is decisive: it reflects the deceased's presumed will...' (Westreich 2018). For the same reasons, it is argued here that presumed consent should be acceptable in Vietnam; however, it should be subject to stricter review and assessment than explicit consent to ensure that it is indeed a reflection of the intent of the deceased. 


\section{The Rights of Parents of a Deceased Person and Demands of Legal Marital Relationship}

As stated earlier, the particular interesting issues in the third Vietnamese PMR case are that (i) whether parents (father or mother) of the deceased have a say in PMR-related issues and (ii) should the requirement of marriage registration be necessary to conduct PMR? At some point earlier [than the Vietnamese case], there was a case involving parents of a deceased person who requested sperm removal from their dying 19-yearold son so that his mother could become a grandmother (Katz (2006) citing Dwyer (2000)). Katz (2006) has argued that solely the spouse of a deceased person should inherit his sperm: “...'the parents' desire to have a grandchild with the genes of the deceased-that is, to 'prolong' the deceased's life though postmortem conception, or to simply continue their lineage-is not among the recognized legal interests". Although some Jewish scholars like Simana seem to favour and advocate for the recognition of a legal right to become grandparents, the existence of this right is in doubt (Simana 2018). In Petithory Lanzmann v. France, Petithory Lanzmann's son died from a cancerous tumour. He had expressed his wish to be a father and to have offspring, including in the event of his death, and had deposited sperm with the CECOS. After his death, the CECOS refused to transmit to the Biomedicine Agency the request for the transfer of the sperm to a healthcare establishment in Israel. Petithory Lanzmann failed in two judicial proceedings before the Paris Administrative court and the Conseil d'État. Petithory Lanzmann then initiated a lawsuit before the ECtHR. Relying on Article 8 of European Convention on Human Rights (ECHR) (right to respect for private and family life), the applicant claimed (i) she was an indirect victim, on behalf of her late son, and (ii) she was a direct victim since she had been deprived of the possibility of becoming a grandparent. Concerning the second claim, the Court considered that Article 8 did not guarantee the right to found a family, particularly the right to become a grandparent, however worthy of the applicant's aspiration to continue the genetic line.

The view that the right to become a grandparent might not be guaranteed was also reflected by the 2003 Guidelines of Israel. As stated earlier, according to the Guidelines, the deceased's spouse is the one in the driving seat to share with the desire for the continuation of the deceased. Citing the case of Keivan Cohen, Kishore argued that the Israeli judicial system has departed from their earlier position, 'in several cases ... the family court has granted permission to the parents to use their deceased son's sperms...' (Kishore 2017). Although there are instances that bereaved parents may have a voice on PMR, e.g. case Keivan Cohen and the bill submitted to the Knesset (Westreich 2018), Israeli courts have not yet departed from the 2003 Guidelines.

In Cohen, an Israeli court allowed the parents of 19-year-old Staff Sergeant Keivan Cohen who was mortally wounded in the Gaza Strip to produce a grandchild using their dead son's sperm to impregnate a single woman who wanted a baby with a known father's identity (Kishore 2017; Fischbach and Loike 2008). Cohen had neither a wife nor even a girlfriend at the time (Fischbach and Loike 2008). A child was born thereafter, living with his biological mother (Kishore 2017). The parents of the deceased enjoyed the limited status of the child's grandparents - to have the visitation rights and the right to provide financial support (Kishore 2017). Later cases like Shaked Meiki and Omri Shahar may demonstrate that Israeli courts have not yet recognized 
'the right to become grandparents'. The parents of Cohen might have become grandparents because Cohen had neither a wife nor a girlfriend who might oppose the PMR process, viz., Israeli courts inclined to individualism rather than communitarianism (Westreich 2018).

In Meiki, Shaked Meiri, a reserve soldier died during a military exercise, and he was childless at that time (Westreich 2018). Meiri's sperm was extracted and preserved following the recommendation of army officials, the agreement of his widow and the active support of his parents (Westreich 2018). Nevertheless, later Meiri's widow remarried and had her own children and objected to the [PMR] process (Westreich 2018). The request of Meiri's parents to use his sperm to impregnate another woman was approved by the family court (Westreich 2018). The widow's appeal to the district court was rejected. The case came before the Supreme Court. The Supreme Court held that parents should not be involved in their child's decision to procreate, and the decision to procreate belongs to the couple (Westreich 2018). The right of the parents to use their dead child's sperm (which can be understood as the right to become grandparents) was rejected (Westreich 2018). The deceased's widow had the exclusive right to make such a decision (Westreich 2018).

In Omri Shahar, Shahar died in a road accident (Westreich 2018). His sperm was extracted and preserved after his death. His parents appealed to a family court to use Shahar's sperm with a surrogate mother and to raise the grandchild. Their application was first approved by a family court but later, following the Supreme Court's decision in case Meiri that the right to procreate was confirmed as reserved exclusively for the spouse. The District court reversed the family court's decision and disallowed the use of Shahar's sperm. At that time, Shahar had a permanent partner, despite supporting the process, she did not want to be an active participant (Westreich 2018). The Supreme Court approved the District Court's decision, and opined that the rationale provided by case Meiri was entirely applicable in case Shahar and the parents could not initiate the process of sperm retrieval without the participation of the spouse, even if she agrees to the process (Westreich 2018).

The existence of the cohabiting partner/spouse and his/her consent and participation in the process are determinant rather than the desire of the deceased's parents. According to Westreich (2018), familial arguments can be found in the Supreme Court decision; nevertheless, the Supreme Court focused on individualistic arguments. Related to the bill, Westreich (2018) argued that although the proposed legislation focuses on familial and communal argumentation, its applicability is limited to fallen soldiers.

Similarly, since a written consent existed in the case $M v$. HFEA of the UK, this case was about solving an individualistic issue, i.e. whether the deceased had given an effective consent to allow her mother to be the deceased's surrogate (Carrington 2016), and the outcome of this case was grounded on individualism. In this case, Mr. and Mrs. $\mathrm{M}$ appealed the refusal to set aside the decision of HFEA to refuse the appellants' application to export to the USA the eggs of their late daughter; A. Mr. and Mrs. M wished to use A's eggs to create an embryo with anonymous donor sperm, and then to implant the embryo in Mrs. M with a view to any child being the grandchild of Mr. and Mrs. M, and aligned with their late daughter's wishes. A had signed a form contemplating that she would be executing the form with a partner (though she had no partner at any relevant time). A had not been given a standard form ('WD form') that is used to enable the donor to specify 'the type of use (e.g. treatment of others or creation of 
embryos) $[\ldots]$ and to stipulate the period of storage'. There was nothing in this form suggesting that the donor of eggs must also give consent to the use of donor sperm. The Statutory Approvals Committee ("the Committee") of the HFEA had rejected the application. Despite acknowledging A's statement to her mother about her mother carrying her babies and her parents bringing them up, the Committee argued that A's wishes during her life did not make clear her intentions in the event of her death. The appeal was allowed and the decision set aside. The Court offered three main arguments.

(i) The Committee had misstated material evidence about A's consent (Carrington 2016).

(ii) The Committee failed to give reasons why A needed information on each step required to give effect to her wish before giving effective consent (Carrington 2016). The Committee did not consider the possibility that A did not want to prescribe matters herself, but leave them for her parents to decide.

(iii) The Committee had not considered what information the HFE Act required to be given to $\mathrm{A}$ in the circumstances of her case.

As mentioned earlier, this paper will not engage with issues related to surrogacy; however, the argument is made here for the acceptance of the deceased's parents' wishes in some cases. We find some support for this in existing cases. In Parpalaix $v$. CECOS, the court determined that 'Alain's parents were the best people to determine the intent of their child when it came to procreation' (Katz 1998). The outcome of case Cohen is also the same as the application of the bereaved parents was accepted. In the context of Vietnam, the support of the parents of deceased persons should be counted, specifically in the case of non-existence of legal marital relationship but the existence of a wedding or in the case where there is a cohabiting relation between a deceased person and a cohabitant. A marriage registration, as a purely administrative process, can be replaced by permission from competent authorities to conduct PMR as long as involved parties accept. Currently, Israel, Greece and Canada bestow permanent partner/cohabitant/common-law partner/sexual partner the right to request for PMR.

\section{Jurisdiction and Dispute Settlement}

In Israel, courts are in charge of deciding PMR issues, ranging from gamete retrieval and permission to IVF to unidentified issues. A request for PMR (PMSR) may be accepted without the participation of courts in the UK, Australia, Canada and Spain. In the UK, Australia and Canada, parties may initiate a suit to request PMR on an ad hoc basis. For Vietnam, with a tendency to avoid legal procedure ('vô phúc đáo tụng đình') (Quỳnh Hoa 2019) influenced by harmony and conformity (Nghĩa 2005; McLeod and Dieu 2001), an approval based on explicit consent is appropriate with distinct procedures regarding verbal and signed written consent. Medical institutions can commence the PMR process (and related techniques, e.g. PMSR) once they receive an application from the deceased's spouse (or the deceased's parents together with the deceased's partner), and when the deceased has given explicit consent. However, courts' jurisdiction should include PMR issues to decide presumed consent cases. In the latter case (presumed consent cases), medical institutions can approve an application for PMR if the application is submitted together with an authorization of a competent court. 
According to the 2015 Civil Procedure Code, the courts have jurisdiction to settle ART cases as either a civil case (i.e. disputes exist) pursuant to Article 28.(6) of the Civil Procedure Code or a civil matter (i.e. disputes do not exist) pursuant to Article 29.(11) of the Civil Procedure Code. Conversely, Article 29.(6) of the 2015 Civil Procedure Code only provides that 'the petitions relating to the surrogacy as falling under the courts' jurisdiction'; further, Article 29.(11) stipulates that 'other petitions relating to marriage and family, except for cases within the jurisdiction of other agencies and organizations as prescribed by law', although likely on these provisions, the jurisdiction of Vietnamese courts over PMR is uncertain due to the uncertainty of the legality of PMR itself.

\section{Time Limitation}

Some intellectuals have argued that a cooling period would be needed before undertaking PMR to prevent hasty and emotional decisions (Bahadur 1996). Some states, such as Belgium and Greece, prescribe PMR must not be conducted earlier than 6 months and no later than 2 years after a death. This requirement is formalistic rather than pragmatic; a medical, psychological and legal consultation and check-up are more appropriate. Hence, while the ceiling is needed to maintain the succession regime and to accelerate bureaucratic work, the time periods can be based on the pace of the consultation and check-up process.

\section{Child's Status}

If the government endorses the practice of PMR, it may set requirements to access this treatment lawfully within its borders. It follows that the child's status (including the nationality of the child and parents-child relation) can be recognized, i.e. the parents' name and nationality of the child can be written down in the civil status certificate, subject to the provisions of laws, e.g. the Law on Civil Status, the Marriage and Family Law, the Civil Code. Nevertheless, it can be problematic in cases where the person seeking PMR is not authorized to conduct PMR. In these cases, the PMR seeker might get access to PMR by means of procreative tourism. Questions on the child status, particularly, the question of parenthood recognition, are then raised. Since children's rights and filiation are prioritized both globally and specifically in Asia, acknowledging the child's identity should not be an obstacle.

Cases related to ARTs such as Mennesson indicate that a child's identity should not be at risk. In Mennesson, the Mennessons were spouses who could not conceive. Surrogacy is unlawful in France; hence, they decided to have a child through a surrogacy arrangement in the USA. The Mennesson twins were born but the parents were unable to obtain recognition in France of the parent-child relationship legally established in the USA. The French Court of Cassation argued that recording such entries in the register would give effect to a surrogacy agreement that was null and void on public policy grounds under the French Civil Code. The court found that there had been no infringement of the right to respect for private and family life since the annulment of the entries had not deprived the children of the maternal and paternal legal relationship recognized by US law and had not prevented them from living in France with Mr. and Mrs. Mennesson. When the case reached the ECtHR, the court 
found that France had violated the children's right to respect for their private life, protected under Article 8 of the ECHR. However, the Court found that the interference was 'in accordance with the law', with a sufficiently predictable basis in French domestic law, and the couple should have known the serious risk that the French courts would not allow the children's births to be registered (Weiss 2019). The interference had a legitimate aim to dissuade procreative tourism, a part of the protection of public health and the protection of the rights and freedoms of others (Weiss 2019). Nevertheless, the interference was not proportionate when it came to the children. The children were confronted with a 'worrying uncertainty as to the possibility of obtaining recognition of French nationality' (Weiss 2019). They would also be unable to inherit from their parents' estate (Weiss 2019).

Weiss (2019) believed that the Mennesson case, broadly speaking, is about the idea that children should not be held responsible for their parents' actions, and that this approach can be applicable to many other similar situations.

Article 1465 of Greek Law provides that if the child was born after the three hundredth day from the dissolution or the annulment of the marriage, the proof of the spouse's paternity burdens the person who makes this claim. The same holds when artificial insemination was carried out after the spouse's death, despite the lack of court authorization to this effect'. Greece acknowledges the right to claim for parenthood in cases where the person conducting PMR is not authorized to do so (but somehow, e.g. procreate tourism, has conducted PMR). Parenthood can be established if sufficient evidence can be offered.

Nevertheless, there should be an exception. Parenthood between a child and a deceased person will not be established if the child is born posthumously as an attempt [of a person except for the deceased's spouse] to abuse [PMR] to inherit from the deceased, i.e. a person who does not have any relation with a deceased person, bribe a physician to access to the deceased's preserved sperm and use the sperm to have a baby to claim for a share of the deceased's estate. Further discussion of this issue will be offered below on the inheritance right of children born posthumously.

\section{Inheritance}

In some jurisdictions, e.g. the USA, there is an incongruity regarding inheritance with respect to PMR. While in re estate of Kolacy, the New Jersey Superior Court decided that the posthumously conceived twins 'should receive the legal status of heirs so that they are able to take property from their parents' (Kishore 2017) (Re Estate of Kolacy, 753 A.2d 1257 (N.J. Super. Ct. App. Div. 2000)); in Astrue v. Capato, the US Supreme Court (Astrue v. Capato 2021132 S. Ct, 541566 US, 2d 887 - Supreme Court 182 L. Ed, 2012) upheld the District Court's decision and refused to bestowed to a biological posthumously born child to the right to receive Social Security benefits as the child did not meet the definition of "child.", as defined in 416(h) of the Social Security Act (31) (Kishore 2017). Against the context of Vietnam, there has not been an official answer to this issue. By analogously applying legal provisions, it can be observed that the inheritance issue can be solved with much controversy in some scenarios and without controversy in some other cases. 
Inheritance may not be controversial in scenarios where:

(i) A deceased person explicitly consents for his partner to conduct PMR and assigns the child born posthumously as one of his successors. In this case, the child can inherit under a will in accordance with Chapter XXII of the 2015 Civil Code on inheritance under wills.

(ii) A deceased person explicitly consents for his partner to conduct PMR and does not leave a will on the division of his estate. According to Article 651 of the 2015 Civil Code, children of the deceased, together with the deceased's spouse and parents, are at the first class of heirs to inherit, viz., these people (the parents, the wife/husband, the children of the deceased) are subjects having exclusive/ prioritized right to inherit at law. As the child is the genetic child of the deceased, born as the deceased's wish, there is no compelling reason to create a new rule to negate the right of children born posthumously to inherit in this case.

(iii) In case of presumed consent, hardly there can be any dispute on inheritance rights of the child born posthumously if the procreation of the child is supported by the deceased's parents. Some accounts can be offered for this position. First, if presumed consent is recognized, viz., the child born posthumously is legally recognized as the child of the deceased, Article 651 of the 2015 Civil Code can be applied to grant the child born posthumously the right to inherit the deceased's estate as in the (ii) scenario. Second, the knowledge of the deceased on the existence of the child may not be relevant. However, there is a further analogy. In the case of an out-of-wedlock child, although a deceased person may not know about the existence of the child when he is alive, the child can inherit from a deceased person (Article 651 of the 2015 Civil Code). Third, recognition of the inheritance right of children born posthumously reflects prosaic reality. The deceased's spouse and the bereaved family are subjects having exclusive/ prioritized right to inherit at law. Supposing that these people support PMR, bearing in mind the importance of family relations in Vietnam, even if authorities do not wish to acknowledge the inheritance right of the child born posthumously, the child can, de facto, inherit thanks to the willingness of his/her mother/father and grandparents. Nevertheless, supposing there is a scenario where the child's mother/father and grandparents all suddenly die before transferring the deceased's estate to the child, if authorities do not acknowledge the inheritance right of children born posthumously, the child's interest can be undermined which can be contrary to the wish of the child's parents and grandparents.

Inheritance may be controversial in scenarios where:

(iv) A deceased person explicitly consents for his partner to conduct PMR. The deceased makes a will to divide his estate and does not assign the child born posthumously as one of his successors. In this case, Article 644 of the 2015 Civil Code on heirs shows that notwithstanding contents of wills can be analogously applicable. According to Article 644.(1) (a) of the 2015 Civil Code, children who are minors of the testator shall be entitled to a share of the estate equivalent to two-thirds of the share that he or she would have received if the estate had been inherited at law (under Article 651) if the testator does not grant such persons an 
inheritance, or grants such persons an inheritance which is less than two-thirds of the share such persons would have received if the estate had been inherited at law. Since the child born posthumously is certainly a minor when the estate is divided, the child should at least enjoy two-thirds of the share as stipulated under Article 644.

(v) The spouse of a deceased person conducts PMR but the decision is opposed by the deceased's parents. Here, the child should have the right to inherit at law under Article 651 of the 2015 Civil Code because (i) the PMR process is carried out as provided by the law, i.e. the child was born legitimately, and (ii) the parenthood has been established by law. By comparing with the case of an out-of-wedlock child, there is no compelling reason to deprive the right to inherit of the child born posthumously in this case. In the case of an out-of-wedlock child, a child can be born as a result of an unlawful relation, e.g. adultery; the child can still inherit from the deceased even if the deceased's family (his parents, wife, children and relatives) opposes this.

(vi) It is challenging to balance the best interests of the child born posthumously as provided under instruments to protect the right of the child (e.g. the Convention on the Rights of the Child and the welfare of society) and the interest of the bereaved family in cases where PMR is conducted to abuse [PMR] to inherit from a deceased person. In such an event, it is reasonable not to grant the inheritance right to children born posthumously in this case because:

a) The deceased does not actively participate in procreating the child and does not know about the PMR process and the existence of the child. Hence, different from the case of an out-of-wedlock child, it is hard to argue that the deceased has any obligation vis-à-vis the child.

b) The law prohibits the conduct of the PMR process in this case. Granting the inheritance right to the child born posthumously can encourage the complicity of abusive acts;

c) The process adversely affects the interest of the bereaved family.

The same considerations apply to the recognition of parenthood. Besides, because all heirs have equal inheritance rights and children of a deceased person are in the first class of heirs to inherit, it is inconsistent to simultaneously recognize parenthood [between the deceased and the child born posthumously] and to deprive the child's inheritance right in this case. Hence, the analogous application of Article 93.(3) of the 2014 Marriage and Family law which reads 'no parenthood shall arise between a person who [anonymously] donates sperm, egg or embryo and the child born with assisted reproductive technology' is appropriate.

Means to bestow the inheritance right to children born posthumously is feasible by either 'inventing' new rules or even by applying existing provisions, e.g. the 2015 Civil Code has two prospective provisions: Article 661 on limitation/postponement of bequeathment ('Where it was the wish of a testator, or where the heirs agree, that an estate is to be distributed only after a certain period of time, it shall be distributed only after such period of time has expired...'), and Article 662 on bequeathment in case of existence new heir ('Where a new heir appears after an estate has been distributed, the estate shall not be re-distributed in kind but the heirs which have received [a share of] 
the estate must pay the new heir a sum equivalent to the share of the estate of such [new heir] at the time of distribution of the estate in proportion to the [respective] share of the estate already received [by each heir], unless otherwise agreed'. The concept of 'new heir' may be altered in response to the modification of 'common child/child born out of ARTs'). Any family disputes related to PMR, e.g. disputes between children born before and after death, can be handled by the court system under Article 26.(5) the 2015 Civil Procedure Code aligned with the solution for each case as suggested in the above paragraphs.

\section{Conclusion}

PMR is a ubiquitous practice and a problematic matter impacted by several factors including social and legal norms. It causes dramatic changes in social relations, particularly within the family institution and inheritance regime. There can be several reasons underneath the authorities' unwillingness to take long-term measures. Nonetheless, from the cultural, ethical and legal perspective, this paper has argued that both prohibiting PMR and allowing PMR implicitly without guiding are unjust because these measures ignore the legitimate desire of both deceased people and bereaved families as well as inflicting undue burdens on the parties and potentially deteriorating their reproductive health by depriving them of the right to information and means to reproduce. Instead of ignoring and disparaging PMR, Vietnam and other countries should take steps to promulgate detailed regulations and guidelines regarding PMR. Long-term measures should take into account lessons drawn from the experiences of other countries together with each country's special cultural traits. Based on contextualization and analogy, taken into account the Vietnamese legal framework and cultural traits, particularly the eagerness to recognize extended family and bloodline continuity, filial duty, spousal debt, respect for elder and deceased people, harmony, etc., prospective regulations concerning PMR, expressed by laws and decrees, should make clear that:

(i) Gametes should be recognized as property with some restrictions. First, gametes are not sellable. Second, only the spouse of the deceased (or the deceased's parents in some instances, as described) can receive/have rights over the gametes.

(ii) Consent should be requested for permission of PMR, whether the consent is presumed or explicit.

(iii) The spouse of the deceased is in the driving seat to request for PMR. Nevertheless, when the wedding has occurred, the desire of the deceased's parents and partner should be counted. The fact that the marriage registration has not been completed should not preclude the right of the bereaved family to claim for conducting PMR.

(iv) If a deceased person leaves an explicit consent to conduct PMR, medical institutions can commence the PMR process (and related techniques, e.g. PMSR) following the request of (i) the deceased's spouse or (ii) the deceased's parents and partner. Otherwise, in case of presumed consent, courts should have the 
jurisdiction to authorize PMR. In the latter case, the PMR process can be commenced following authorization of the eligible court.

(v) IVF and embryo transference (as a stage of PMR process) can only be commenced within 2 years after a death, after the completion of the consultation and check-up process.

(vi) Except for some instances, e.g. the abuse to inherit from the deceased [of a person except for the deceased's spouse], the child's identity and the child's right to inherit from the deceased should be guaranteed. Concerning the inheritancerelated issues, the share of the child is determined on a case-by-case basis aligned with the 2015 Civil Code. Article 661 on limitation/postponement of bequeathment and Article 662 on bequeathment in case of existence new heir of the Civil Code can serve for leaving a share to children born posthumously; nevertheless, the government can invent any new provision for this purpose.

Acknowledgements We wish to thank the two anonymous reviewers for their constructive critical comments. The authors are grateful to Professor Graeme T. Laurie and the Editorial Team for assistance in finalizing this paper. All errors are the responsibility of the authors. Our thanks go as well to Trang Thi Thu Tran of Hanoi Law University for her kind comments; Attorney Thanh Van Le of SureLaw Law Firm for his kind support; our friends, colleges of University of Economics and Law, Vietnam National University HCMC and University of Law, HCMC, for their comments and encouragement.

Author Contributions All authors contributed to the study conception and design. Material preparation and analysis were performed by Hai Thanh Doan and Diep Thi Phuong Doan. The first draft of the manuscript was written by Hai Thanh Doan and Diep Thi Phuong Doan with the supervisor and revision of Nguyen Kim The Duong. All authors commented on previous versions of the manuscript. All authors read and approved the final manuscript.

\section{Compliance with Ethical Standards}

Conflict of Interest The authors declare that they have no conflict of interest.

\section{References}

Amorós, Esther Farnós. 2015. Donor anonymity, or the right to know one's origins? Catalan Social Sciences Review 5: 1-10. https://doi.org/10.2436/20.3000.02.21.

Anh, Đào Duy. 2002. Việt Nam văn hóa sủ cương. Văn hóa-thông tin.

Anh, Lan. 2018. Bộ Y Tế Khẳng Định Phải Tuân Theo Luật [The Ministry of Health asserts an obligation to comply with the law]. Tuoi Tre Online, 26 December 2018. https:/tuoitre.vn/vu-xin-thua-ke-tinh-trungbo-y-te-khang-dinh-phai-tuan-theo-luat-20181226185401836.htm.

Anh, Lan. 2019. Tranh Cãi Pháp Lý Việc Trữ Tinh Trùng Sau Khi Người Thân qua Đời [A legal dispute over sperm storage after a relative dies]. Tuoi Tre Online, 8 January 2019. https://tuoitre.vn/tranh-cai-phap-lyviec-tru-tinh-trung-sau-khi-nguoi-than-qua-doi-20190108170011224.htm.

Anh, Toan. 2001. Phong Tục Thò̀ Cúng Tổ Tiên Trong Gia Đình Việt Nam [Ancestor Worship in Vietnamese Families]. Văn hóa dân tộc.

Aziza-Shuster, Evelyne. 1994. Ethics and society: a child at all costs: posthumous reproduction and the meaning of parenthood. Human Reproduction 9 (11): 2182-2185. https://doi.org/10.1093/oxfordjournals. humrep.a138414. 
Bahadur, G. 1996. Posthumous assisted reproduction: posthumous assisted reproduction (PAR): cancer patients, potential cases, counselling and consent. Human Reproduction 11 (12): 2573-2575. https://doi.org/10.1093/oxfordjournals.humrep.a019170.

Bahadur, G. 2002. Death and conception. Human Reproduction 17 (10): 2769-2775. https://doi.org/10.1093 /humrep/17.10.2769

Barton, Sara E., Katharine F. Correia, Shirley Shalev, Stacey A. Missmer, Lisa Soleymani Lehmann, Divya K. Shah, and Elizabeth S. Ginsburg. 2012. Population-based study of attitudes toward posthumous reproduction. Fertility and Sterility 98 (3): 735-740. https://doi.org/10.1016/j.fertnstert.2012.05.044.

Batzer, Frances R., Joshua M. Hurwitz, and Arthur Caplan. 2003. Postmortem parenthood and the need for a protocol with posthumous sperm procurement. Fertility and Sterility 79 (6): 1263-1269. https://doi. org/10.1016/S0015-0282(03)00384-4.

Callaway, Ewen. 2015. UK mapped out by genetic ancestry. Nature. https://doi.org/10.1038/nature14230.

Carbonnier, Jean. 2000. Droit Civil, Tome 1: Les Personnes. Paris: Presses Universitaires de France.

Carrington, Fiona. 2016. R (on the application of $\mathrm{Mr}$ and $\mathrm{Mrs} \mathrm{M}$ ) v human fertilisation and embryology authority: [2016] EWCA Civ 611: Sir James Munby (President of the Family Division), Arden and Burnett LJJ: 30 June 2016. Oxford Journal of Law and Religion 5 (3): 634-635. https://doi.org/10.1093 /ojlr/rww026.

Collins, Rebecca. 2005. Posthumous reproduction and the presumption against consent in cases of death caused by sudden trauma. Journal of Medicine and Philosophy 30 (4): 431-442. https://doi.org/10.1080 /03605310591008612.

Côté, Stéphanie, Aliya Oulaya Affdal, Isaac Jacques Kadoch, Pavel Hamet, and Vardit Ravitsky. 2014. Posthumous reproduction with surplus in vitro fertilization embryos: a study exploring users' choices. Fertility and Sterility 102 (5): 1410-1415. https://doi.org/10.1016/j.fertnstert.2014.07.1202.

Điện, Nguyễn Ngọc. 2018. Civil Law Textbook [Giáo Trình Luật Dân Sụ]. Vietnam National Unversity, HCMC Press [Nhà xuất bản Đại học Quốc gia Thành phố Hồ Chí Minh].

Dinh, Kim. 1970. Origin of Vietnam's philosophy. Hanoi: An Tiem Publishers.

Dwyer, L.A. 2000. Dead daddies: issues in postmortem reproduction. Rutgers Law Review 52 (3): 881-910.

Ethics Committee of the American Society for Reproductive Medicine. 2018. Posthumous retrieval and use of gametes or embryos: an ethics committee opinion. Fertility and Sterility 110 (1): 45-49. https://doi. org/10.1016/j.fertnstert.2018.04.002.

European Society of Human Reproduction and Embryology. 2016. Children growing up in solo mother families are well adjusted and developing well: they nevertheless have questions about the absence of a father . ScienceDaily, 4 July 2016. https://www.sciencedaily.com/releases/2016/07/160704082717.htm.

Fan, Ruiping. 2007. Confucian familism and its bioethical implications. In The Family, Medical DecisionMaking, And Biotechnology Critical Reflections on Asian Moral Perspectives, ed. Shui Chuen Lee, 1525. Dordrecht: Springer.

Fischbach, Ruth L., and John D. Loike. 2008. Postmortem fatherhood: life after life. Lancet 371 (9631): 21662167. https://doi.org/10.1016/S0140-6736(08)60942-3.

Hai, Thanh. 2018. Gian Nan Sinh Con Với Người Đã Mất [Arduous having children with the deceased]. Vietnam: VTV1. https://www.youtube.com/watch?v=Gc9EXMOS54A.

Hans, Jason D. 2014. Posthumous gamete retrieval and reproduction: would the deceased spouse consent? Social Science \& Medicine 119: 10-17. https://doi.org/10.1016/j.socscimed.2014.08.010.

Hiep, Hoang Phuoc, Per Berling, Nguyen Minh Man, Hoang Thanh Tung, Viola Bostrom, and Erik Persson. 1996. The Vietnamese legal system. Joint Paper by Vietnamese Ministry Of Justice and Swedish Embassy Officials.

Hill, Thomas E., Jr. 1992. Kantian pluralism. Ethics 102 (4): 743-762. https://doi.org/10.1086/293446.

Hui, Edwin. 2001. A Confucian ethic of medical futility. In Confucian Bioethics, ed. Ruiping Fan, 127-66. Dordrecht: Kluwer Academic Publishers.

Rosenblum, Irit. 2013. The biological willTM - a new paradigm in ART? https://www.newfamily.org. il/en/4905/the-biological-will\%E2\%84\%A2-\%E2\%80\%93-a-new-paradigm-in-art/. Accessed 15 July 2013.

$\mathrm{Yu}$, Insun. 1978. Law and family in seventeenth and eighteenth century Vietnam. PhD diss., University of Michigan.

Kant, Immanuel. 1785. Grundlegung zur Metaphysik der Sitten [Groundwork for the metaphysics of morals]. Riga: Johann Friedrich Hartknoch.

Katz, G. A. 1998. Parpalaix v. CECOS: protecting intent in reproductive technology. Harvard Journal of Law \& Technology 11 (3): 683-698.

Katz, Katheryn D. 2006. Parenthood from the grave: protocols for retrieving and utilizing gametes from the dead or dying. University of Chicago Legal Forum 2006 (1): 289-316. 
Kelley, Liam C. 2020. The centrality of 'fringe history': Diaspora, the internet and a new version of Vietnamese prehistory. International Journal of Asia-Pacific Studies 16 (1): 71-104. https://doi. org/10.21315/ijaps2020.16.1.3.

Kishore, R.R. 2017. Born from the ashes: ethics and law of posthumous reproduction. Eubios Journal of Asian and International Bioethics 27 (6): 190-200.

Kramer, Matthew H. 2001. Do animals and dead people have legal rights? Canadian Journal of Law \& Jurisprudence 14 (1): 29-54. https://doi.org/10.1017/S0841820900002368.

Lan, Le Thi. 2016. Common root of three religions (三敉同源) in history of Vietnamese thoughts. Studies in Confucianism 36: 535-61. https://doi.org/10.18216/yuhak.2016.36..019.

Landau, R. 2004. Posthumous sperm retrieval for the purpose of later insemination or IVF in Israel: an ethical and psychosocial critique. Human Reproduction 19 (9): 1952-1956. https://doi.org/10.1093 /humrep/deh360.

Lee, Robert G, and Derek Morgan. 2001. Human fertilisation and embryology: regulating the reproductive revolution. London: Blackstone Press.

Li, ChenYang. 2018. Community without harmony? A Confucian critique of Michael Sandel. In Encountering China: Michael Sandel and Chinese Philosophy, ed. Michael J. Sandel and Paul J. D’Ambrosio. Cambridge, MA: Harvard University Press.

Lin, Yun-Hsien Diana. 2013. Posthumous assisted reproduction in the East Asian context: towards a comprehensive framework of regulation. Asian Bioethics Review 5 (2): 93-109. https://doi.org/10.1353 /asb.2013.0018.

Luat, Phap. 2018. PGS-TS Đỗ Văn Đại - ĐH Luật TP.HCM Cho ý Kiến về Việc Thừa Kế Tinh Trùng [Assoc. Prof. Dr. Do Van Dai - University of Law HCMC Opine on Sperm Inheritance]. LawNet, 25 December 2018. https://lawnet.thukyluat.vn/posts/t9266-pgs-ts-do-van-dai-dh-luat-tp-hcm-cho-y-kien-ve-viec-thuake-tinh-trung.

McLeod, Mark W., and Nguyen Thi Dieu. 2001. Culture and customs of Vietnam. Westpoint, CT: GreenWood Press. https://doi.org/0-313-30485-8.

Mestechkina, Tatyana, Nguyen Duc Son, and Jin Y Shin. 2014. Parenting in Vietnam. In Parenting across Cultures: Childrearing, Motherhood and Fatherhood in Non-Western Cultures, ed. Helaine Selin, 47-57. Dordrecht: Springer.

Cook, Michael. 2018. In post-one-child-policy China posthumous conception is a matter of desperation. Bioedge, 14 April 2018. https://www.bioedge.org/bioethics/in-post-one-child-policy-china-posthumousconception-is-a-matter-of-despera/12654.

Bennett Moses, Lyria K. 2014. The Problem with Alternatives: The importance of property law in regulating excised human tissue and in vitro human embryos. In Persons, Parts and Property, ed. Imogen Goold, Kate Greasley, Jonathan Herring and Loane Skene, 197-214. Oxford: Hart Publishing.

Nakhuda, Gary S., Jeff G. Wang, and Mark V. Sauer. 2011. Posthumous assisted reproduction: a survey of attitudes of couples seeking fertility treatment and the degree of agreement between intimate partners. Fertility and Sterility 96 (6): 1463-1466.e1. https://doi.org/10.1016/j.fertnstert.2011.09.018.

Nghĩa, Pham Duy. 2005. Confucianism and the conception of the law in Vietnam. In Asian Socialism and Legal Change: The dynamics of Vietnamese and Chinese Reform, ed. John Gillespie and Pip Nicholson, 76-90. Canberra, ACT: ANU Press. https://doi.org/10.22459/aslc.08.2005.04.

Nguyễn, Tài Đông. 2013. Tam Giáo Đồng Nguyên và Tính Đa Nguyên Trong Truyền Thống văn Hóa Việt Nam [Three religions and pluralism in Vietnamese traditional culture]. Khoa học xã hội Việt Nam 5 (66): 35-43.

Orr, Robert D., and M. Siegler. 2002. Is posthumous semen retrieval ethically permissible? Journal of Medical Ethics 28:299-302. https://doi.org/10.1136/jme.28.5.299.

Ossorio, Pilar N. 2011. Myth and Mystification: The Science of Race and IQ. In Race and the Genetic Revolution: Science, Myth, and Culture, ed. Sheldon Krimsky and Kathleen Sloan, 173-194. New York, NY: Columbia University Press. https://doi.org/10.7312/krim15696-010.

Parizer-Krief, Karène. 2016. Post mortem procreation in French and British law. Culture and Research 5: 91112. https://doi.org/10.26262/culres.v5i0.4955.

Pastuszak, A.W., W.S. Lai, T.-C. Hsieh, and L.I. Lipshultz. 2013. Posthumous sperm utilization in men presenting for sperm banking: an analysis of patient choice. Andrology 1 (2): 251-255. https://doi. org/10.1111/j.2047-2927.2012.00027.x.

Công lý. 2014. Cần Quy Định về Việc 'người Chết Sinh Con [It Is Necessary to Regulate Postmortem Reproduction]. Công lý, 1 March 2014. http://congly.vn/phap-luat/dien-dan-cong-ly/can-quy-dinh-veviec-nguoi-chet-sinh-con-41974.html.

Quinn, Joseph R. 1973. Medicine and public health in the People's republic of China. National Institutes of Health. Bethesda, MD: Fogarty International Center. 
Quỳnh Hoa, Dương. 2019. Vai trò của luật sư trong tố tụng dân sự Việt Nam [Role of lawyer in Vietnamese civil procedure]. Khoa học xã hội Việt Nam 2019 (6): 74. https://vjol.info.vn/index. php/khxhvn/issue/view/4100. Accessed 16 July 2020.

Raposo, Vera Lúcia. 2012. Reprodução Assistida, Dois Modelos de Regulação: Portugal vs. Espanha [Assisted Reproduction, Two Models of Regulation: Portugal v. Spain]. Jornal Brasileiro de Reprodução Assistida 16 (1): 35-43.

Ravitsky, Vardit. 2017. The right to know one's genetic origins and cross-border medically assisted reproduction. Israel Journal Health Policy Research 6 (1): 3. https://doi.org/10.1186/s13584-016-0125-0.

Reid, Kenneth. 2015. Body parts and property. SSRN. https://doi.org/10.2139/ssrn.2644303.

Rothman, Cappy Miles. 1980. A method for obtaining viable sperm in the postmortem state. Fertility and Sterility 34 (5): 512. https://doi.org/10.1016/S0015-0282(16)45147-2.

Schaber, Peter. 2005. Ethical Pluralism. In Studies into the Foundations of an Integral Theory of Practice and Cognition, ed. T. Nitta, 139-156. Sapporo: Hokkaido University Press.

Schiff, Anne Reichman. 1999. Posthumous conception and the need for consent. Medical Journal of Australia 170 (2): 53-54. https://doi.org/10.5694/j.1326-5377.1999.tb126879.x.

Shapiro, E. Donald, and Benedene Sonnenblick. 1987. Widow and the sperm: the law of post-mortem insemination. Journal of Law \& Health 1 (2): 229. https://engagedscholarship.csuohio.edu/jlh/vol1/iss2 /5/. Accessed 16 July 2020.

Shebbeare, Monique. 2016. Can a spouse use stored sperm, eggs or embryos after their partner dies? Fertility Law BC, 23 November 2016. https:/www.fertilitylawbc.com/2016/11/23/can-a-spouse-use-storedsperm-eggs-or-embryos-after-their-partner-dies/.

Simana, Shelly. 2018. Creating life after death: should posthumous reproduction be legally permissible without the deceased's prior consent? Journal of Law and the Biosciences 5 (2): 329-354. https://doi. org/10.1093/jlb/lsy017.

Smolensky, Kirsten Rabe. 2008. Rights of the dead. Hofstra Law Review 37 (3): 763. https://scholarlycommons.law.hofstra.edu/hlr/vol37/iss3/4. Accessed 16 July 2020.

Strong, Carson. 1999. Ethical and legal aspects of sperm retrieval after death or persistent vegetative state. Journal of Law, Medicine \& Ethics 27 (4): 347-358. https://doi.org/10.1111/j.1748-720X.1999.tb01470.x.

Thêm, Trần Ngọc. 2009. Cơ Sở Văn Hóa Việt Nam [Foundations of Vietnamese culture]. Hanoi: NXB Giáo Dục [Education Publisher].

Tran-Duc-Thao. 1947. Vietnam and Eastern Asia. Far Eastern Quarterly 6 (4): 409-413. https://doi. org/10.2307/2049436

Tremellen, Kelton, and Julian Savulescu. 2015. A discussion supporting presumed consent for posthumous sperm procurement and conception. Reproductive BioMedicine Online 30 (1): 6-13. https://doi. org/10.1016/j.rbmo.2014.10.001.

Tùng, Thanh, and Liên Châu, and Lê Nga. 2013. Thụ Tinh Từ Tinh Trùng Người Đã Chết: Pháp Luật Vẫn Ghi Nhận Tên Cha [Insemination from dead sperm: the law still records father's name]. Thanh Niên, 30 December 2013. https://thanhnien.vn/suc-khoe/thu-tinh-tu-tinh-trung-nguoi-da-chet-phap-luat-van-ghinhan-ten-cha-462395.html.

Ueda, Noriyuki, Nobutaka Kushi, Mikiya Nakatsuka, Tatsuyuki Ogawa, Yoshiko Nakanishi, Keisuke Shishido, and Tsuyoshi Awaya. 2008. Study of views on posthumous reproduction, focusing on its relation with views on family and religion in modern Japan. Acta Medica Okayama 62 (5): 285-296. https://doi.org/10.18926/amo/30967.

UNFPA, OHCHR, and the Danish Institute for Human Rights. 2014. Reproductive rights are human rights: a handbook for National Human Rights Institutions. New York, NY: United Nations Population Fund, Office of the United Nations High Commissioner for Human Rights, and the Danish Institute for Human Rights. https://www.unfpa.org/publications/reproductive-rights-are-human-rights. Accessed 16 July 2020

Vuong, Quan-Hoang, Quang-Khiem Bui, Viet-Phuong La, Thu-Trang Vuong, and Viet-Ha T. Nguyen, Manh-Toan Ho, Hong-Kong T. Nguyen, and Manh-Tung Ho. 2018. Cultural additivity: behavioural insights from the interaction of Confucianism, Buddhism and Taoism in folktales. Palgrave Communications 4 (1): 143. https://doi.org/10.1057/s41599-018-0189-2.

Wang, Qingjie. 2001. The Confucian filial obligation and care for aged parents. In Confucian Bioethics, ed. Ruiping Fan, 235-57. Dordrecht: Kluwer Academic Publishers.

Wardle, Lynn D. 2006. Global perspective on procreation and parentage by assisted reproduction. Capital University Law Review 35: 413.

Weiss, Adam. 2019. Mennesson v France and advisory opinion concerning the recognition in domestic law of a legal parent-child relationship between a child born through a gestational surrogacy arrangement abroad and the intended mother. Statelessness and Citizenship Review 1 (2): 343-349. https://statelessnessandcitizenshipreview.com/index.php/journal/article/view/115. Accessed 16 July 2020. 
Westreich, Avishalom. 2018. Present-day posthumous reproduction and traditional levirate marriage: two types of interactions. Journal of Law and the Biosciences 5 (3): 759-785. https://doi.org/10.1093 /jlb/lsy026.

Whitmore, John K. 1984. Social organization and Confucian thought in Vietnam. Journal of Southeast Asian Studies 15 (2): 296-306. https://doi.org/10.1017/S0022463400012534.

Hoa, X. 2018. Tinh Trùng Có Phải Là Tài Sản Thừa Kế? [Is Sperm an Inheritance?]. Pháp luật, 17 December 2018. http://baophapluat.vn/hoi-dap-phap-luat/tinh-trung-co-phai-la-tai-san-thua-ke-429840.html.

Yến, Hoàng. 2018. Mẹ Muốn Thừa Kế... Tinh Trùng Của Con [A Mother Wants To Inherit ... Her Son Sperm]. Pháp luật, 20 December 2018. https://plo.vn/phap-luat/me-muon-thua-ke-tinh-trung-cua-con808943.html.

Young, Hilary. 2014. Presuming consent to posthumous reproduction. Journal of Law and Health 27 (1): 68. https://engagedscholarship.csuohio.edu/jlh/vol27/iss1/6. Accessed 16 July 2020.

Zini, Armand, and Victor Mak. 2001. Postmortem sperm retrieval is not a urologist's duty. Contemporary Urology 13 (7): 36.

\section{Select Cases}

Astrue v. Capato: Astrue v. Capato 2021132 S. Ct, 541566 US, 2 d 887 - Supreme Court 182 L. Ed, 2012. Blood: R v Human Fertilisation and Embryology Authority, ex parte Blood [1997] 2 All ER 687 (Court of Appeal), (1997) 35 BMLR 1 (High Court and Court of Appeal); (UK).

Davis v. Davis: Davis v. Davis, 842 S.W.2d (US).

Hecht: Hecht v. Superior Court (Kane), 20 Cal. Rptr. 2d 275, 283 (Cal. 1993) (US).

K.L.W.: K.L.W. v. Genesis Fertility Centre, 2016 BCSC 1621 (Can).

M v. HFEA: R (M) v Human Fertilization and Embryology Authority [2016] EWCA Civ 611 (UK).

Mennesson: Mennesson v. France, Application no 65192/11, Council of Europe: European Court of Human Rights, 26 June 2014.

Nahmani v. Nahmani: CFH 2401/95 Nahmani v. Nahmani [1995-6] ISR.L.REV.1 (Isr).

Parpalaix v. CECOS: Parpalaix v Centre d'études et de conservation du sperme (CECOS), TGI, Créteil (1re ch. civ.), 1 Aug 1984, Gazette du Palais, 18 Sept 1984 (Fra).

Petithory Lanzmann v. France: Petithory Lanzmann v. France, (application no. 23038/19), Council of Europe: European Court of Human Rights, 423 (2019).

Re Estate of Kolacy: Re Estate of Kolacy, 753 A.2d 1257 (N.J. Super. Ct. App. Div. 2000)) (US).

Re the estate of the late Mark Edwards: Re the estate of the late Mark Edwards [2011] NSWSC 478 (Aus). Yearworth: Yearworth and others v North Bristol NHS Trust ([2009] EWCA Civ 37; [2010] QB 1) (UK).

Publisher's Note Springer Nature remains neutral with regard to jurisdictional claims in published maps and institutional affiliations. 